UDC $621.311 .61 .025 .2: 621.3 .018 .3: 621.335$

621.314.63.014.2.077.65

\title{
多分割サイリスタ制御整流回路の交流側 高調波電流軽減の一提案
}

$\begin{array}{lllll}\text { 正員 松 } & \text { 橋 } & \text { 登喜雄 } & \text { (铁道技研) } \\ \text { 非会員 } & \text { 長 } & \text { 井 } & \text { 貞 雄 } & \text { (富山工専) } \\ \text { 正員 } & \text { 雨 } & \text { 宮 } & \text { 好 } & \text { (文 }\end{array}$

\section{1. まえがき}

交流式電気鉄道における電気車では，速度制御特性 として優れている直流直巻電動機駆動力として使用 するため単相整流装置を電気車にとう載して直流電源 を得ており，直流電王・電流の制御ししてタップ制御 万式が広く用いられている。

近時サイリスタの大容量化に伴い，電圧電流の制御 としてサイリス多制御方式が実用されるようになって きた。サイリスタ制御を用いた単相整流装置におりる 電王・電流の制御は，サイリス夕の性質上電正・電流 の波形を一部裁断主る制御之なるので，直流倒電死㫫 びに交流側電流波形はダイオードを使用した単相整流 装置の場合より著しくひずもこととなる。このひずみ の大きな交流電流がそのまま給電線路に流れると, 系 統譏器 (例えばき電用変压器, 単美变厈器, 周波数变 換㙨，力率改善用機器など)，系統保護装置(距離継電 器, 故障検出装䈯など) 並ざに列車速度指令情報, 列 車位置情報などに悪影響を与えるとともに，電車線， 軌道などに伴う大地帰路回路の構成加ら，鉄道線路に 近接平行する弱電流線施設に誘導現象による妨害を与 えることとなる。

最近，電気車の無接点化，メンテナンスフリー化な どに加えて省エネルギーの観点加ら再度交流電気車用 としてサイリスタ制御方式が検討されるようになり， 制御に伴って発生する交流側高調波電流の整減刘策が 一温重要な課題となってきている。交流電気車用サイ リスタ制御整流回路におりる交流側高調波電流の軽隇

\footnotetext{
A Proposal for AC Side High-Harmonic Reducing Method of Multiplit Thyristor Control Rectifying Circuit. By Tokio Matsuhashi, Member (Railway Technical Research Institute, JNR), Sadao Nagai, Non-member (Toyama Technical College) \& Yoshifumi Amemiya, Member (Nagoya University).

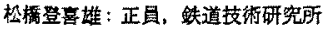

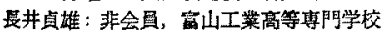
雨宮好文：正員，名古堅大学工学部
}

詨策としては，整流器用主変正器二次側分割数の增 加，交流側軽流りアクタンスの增大，共振形フィルタ の探用，位相制御方式の改度など(1)-(5) の検討が行な われ，現車による試験む実施されている。

サイリスタ制御整流装犆花使用する電気車では力行 制御のみ行なう場合，サイリスタに点弧信号を与える だけで直流側電生の制御ができる混合ブリッジ整流回 路が用いられている。そこでは，サイリス夕の制御に 伴って交流側に発生する高調波電流の軽減と力行中に おける平均力率の改善を目的として，整流器用主变圧 器の三次側を復数個に分割し，各分割に混合ブリッジ 回路を接続し，その直流側を直列に接続して負荷の直 流直巻電勳機に供給する方法をとっている。

この回路における直流侧電生・電流の制御方法は， まず第 1 分割に接続された混合ブリッジ（以下第 1 ユ ニットと路称）について值相制御灾行ない，出力苴流 電王を制御する。第 1 ユニットの制御位相が $\pi$ から0

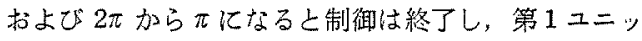
卜は第 1 分割最大の直流出加電圧を生ずる。ついで第 2 ユニットの位相制御人と入る。このとき出力直流電 生は第 1 ユニットと第 2 ユニットとの和となり，位相 制彻とともに增加し負荷の直流電動機は涑度を增して いくこととなる。なお第 2 ユニットの制御終了传は第 3，第4ユニットへと制御方進められるとととなる。 本論文ではこれを逐時制御方式と呼ぶこととする。

筆者らは先に，電気車用サイリス夕制御整流回路に おける高調波軽減のためのサイリス夕制御方式として 強制消呱制御方式亚びに多重制御方式について提案し t。o

強制消弧制钿方式 ${ }^{(2)}$ は単相混合ブリッジ整流回路に おいて $\pi / 2-\alpha$ および $3 \pi / 2-\alpha$ でサイリスタを点弧制 兓し， $\pi / 2+\alpha$ および $3 \pi / 2+\alpha$ でサイリスタを消弧制 御し， $\alpha$ が $\pi / 2$ 亡なる制御終了を待って第 2 ，第 3 ,

第 4 ユニットへと順次第 1 ユニットと同様な位相制御 
を行ない，直流䨳压を制衔するものである。これによ り交流電流に合岀れる第 3 調波電流は，第 2 ユニット 以降の制御中常に逐時制御方式に比へて軽減するこし が可能で，位相制御の中心となる位相角の選び方によ り打率改善のできることも示した。

桀重制御方式(5)は電気車用サイリスタ制御整流回路 のうち，力行制御立びに電力回生制御を行なう䭪合に 用いられるサイリスタブリッジ整流回路の制御方式に 関するあのである。ここでは単相サイリスタブリッジ 整流回路のサイリスタ制御で必要な $\gamma_{\text {min }}$ 制御に伴っ て発生する高調波量を狮制するため，各ニニットの位 相制御に㕲いて一定角度をずらせて対称制御を行なう とともに各ニニットを多重化することにより， $\gamma_{\min }$ 制

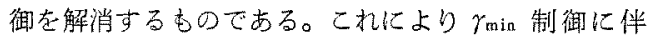
って発生す歹高調波量の㸡制, 特定高調波の軽減, 主 变圧器二次分割効果の增大，電力回生制做移行への簡 易化などが得られた。

本諭文で提案する新たな制御方式は，単相混合ブリ ッジ整流回路に拈いて全ユニットのサイリス夕制御を 同時に作動する万法である。こ㧈を本論文では同時制 御方式上呼ふししにする。之の具体的制御方法は，各 ユニットの制御伎相角の組合甘支一次㑡交流電流につ いて含有する全高調波量の最小，等俩妨害電流の最 小，または特定高調波の最小などの制﨏目樽に合せて 定め，各ユニット变同時江動作制䣦するもので，目標 值制御力式または最避值制御方式し屯いうべき方法て ある。

\section{2. 新たな制御方式}

第1图はサ1リス多位相制御老採用した塑相多分割 混合ブリッジ整流回路の例しして, 整流器用主変在器 の二次唰分割数加 4 個の場合老示した。

この回路を用いた電気車に扔ける逐時制解方式では 力行制期の場合，まず第 1 ユニットのサイリスタにつ

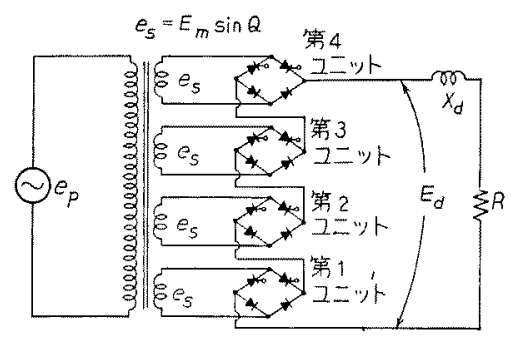

策 1 图多分割サイリス多制御整流回路

Fig. 1. Multisplit thyristor control rectifying circuit.
いて位相 $\pi$ および $2 \pi$ 加ら制御を行ない，直流出力電 压を直流直巻電動機に加えて起動する。次で，第 1 工 ニットの制御位相角が 0 および $几$ になると第 1 ユニッ トはそのままとし，第 2 ュットのサイリスタについ て第 1 ユニットと同様位相制御を行なう。とのとき出 力直流電玨は各整流器ブリッジの出力側で加え合わさ れ，電圧の增加と之もに電動機速度が㮌次上昇するこ ととなる。なお，制御は順次第 3，第4ユニットへと 進められるとととなる。このように逐時制御では各工 ニットの制御が電気車の速度に往って第 1 ユニットか ら順に位相制御されているが，各ユニットは独立に制 御機能を有するので真荷として必要な出力直流電生が 得られれば，どのユニットでも任意に制御するこ上が 可能であるということになる。

本論文ではこの点に着目した位相制御方式で，ここ では全ュニットの動作を同時に行ない，直流側で必要 な電左を全ユニットの位相制御に伴う出力電圧の合成 として得るととあに，各ニニットの制御位相角の組合 せを高調波電流の軽減目標に合せて決定制御するもの である。制御の具体的方法は，第 1 図において，第 1 ユニットの制御角を $\alpha_{1}$, 第 2 ユニットの制御角を $\alpha_{2}$, 第3，第 4 ユニットの制御角を $\alpha_{3}, \alpha_{4}$ とし $\left(\alpha_{1} \leq \alpha_{2} \leq\right.$ $\left.\alpha_{3} \leq \alpha_{4}\right)$ 同一半波内で順次位相制御行なうあのとし， この制御角の組合せを出力直流電圧の大きさを制約条 件として高調波電流最少などの目標に合せて制御する あのである。

〈2.1〉 全高調波量を最小とする制御 第1䀩の ように, 整流器用主変压器の二次側巻線が 4 分割され た単相混合ブリッジ整流回路において，酉流側リアク トルを非常に大きくして直流雷流を完全平滑とすれば 交流側雷流波形は，ほぼ台形波に近い波形しなる。な 方，交流側インピーダンスは主変圧器の一次，二次巻 数比が大きい場合（例えげ ED 755 形電気機関車では 一次電生 $20 \mathrm{kV}$, 二次電压 $307 \mathrm{~V} \times 4)$ では二次電圧で は二次側変換インピーダンスが小さく，主変圧器の瀮 れりアクタンス（通常電気機閔車では電圧変動率を考 慮して小さく設計される。しかし，高調波軖減対策上 しては大きいことが望まれている ED 755 形でば二次 1 巻線むたり $0.0092 \Omega$ 程度）あ小さいと考えると交 流側電流波形における転流区間も短かくなり，ほほ方 班波の皘重放波玌としてモデル化することができる。

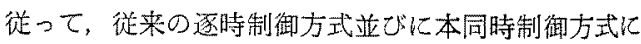
おり万各部の電圧・霓流波形の概形は第2 图のように モデル化して描くことがでさる。佂って，これらのモ デル化波形から逐時制御方式における直流俔平均電圧 $E_{d}$ 扝よび交流側霆流 $I_{a}$ は次の上うに与えられる。 


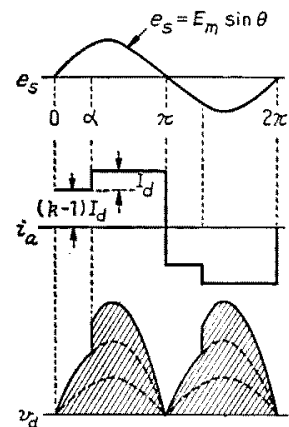

逐時制御

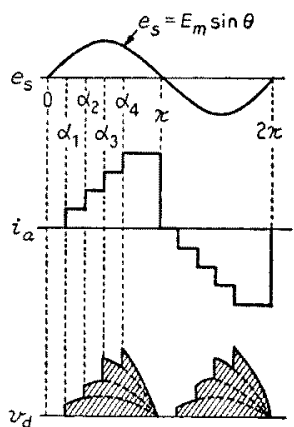

同时制㭪
第 2 図 モデル化波形

Fig. 2. Idealiyed current and voltage wave form.

$$
\begin{aligned}
& E_{d}=\frac{E_{m}}{\pi}(2 k-1+\cos \alpha) \ldots \\
& I_{a}=\frac{I_{d}}{\sqrt{\pi}} \sqrt{k^{2} \pi-(2 k-) \alpha}
\end{aligned}
$$

但し， $k=$ 導通中のユニット数， $\alpha=$ 制御角 本論文の同時制御方式では第 2 図加ら直流側平均電圧 $E_{d}$ および交流側電流の寒効值 $I_{a}$ は次のように与え られる。

$$
\begin{gathered}
E_{d}=\frac{E_{m 2}}{\pi}\left(m+\cos \alpha_{1}+\cos \alpha_{2} \ldots \ldots+\cos \alpha_{m}\right) \\
\ldots \ldots \ldots \ldots \ldots \ldots \ldots \ldots \ldots \ldots \ldots \ldots \ldots \ldots \ldots \\
I_{a}=\frac{I_{d}}{\sqrt{\pi}} \sqrt{m^{2} \pi-\alpha_{1}-\alpha_{2} \cdots \cdots \cdot(2 m-1) \alpha_{m}}
\end{gathered}
$$

但し, $m=$ 主変仕器二次側の二ニット数

また，第 $n$ 調波成分の奏效值 $I_{n}$ は次の上うに与え られる。

$$
\begin{aligned}
I_{n} & =\frac{\sqrt{2} I_{d}}{n \pi} \sqrt{\left(\sin n \alpha_{1}+\sin n \alpha_{2} \ldots \ldots\right.} * \\
& * \overline{\left.+\sin n \alpha_{m}\right)^{2} \cdots \cdots+\left(m+\cos n \alpha_{1}\right.} * \\
& * \overline{\left.+\cos n \alpha_{2} \ldots \ldots+\cos n \alpha_{m}\right)^{2}} \ldots \ldots \ldots
\end{aligned}
$$

従って，交流側電流に含まれる高調波成分の実效值 を $I_{h}$ とすると次のようにる。

$$
\begin{aligned}
I_{h}= & I_{d}\left[\frac{1}{\pi}\left\{m^{2} \pi-\sum_{k=1}^{m}(2 k-1) \alpha_{k}\right\}\right. \\
& -\frac{2}{\pi^{2}}\left\{\left(\sum_{k=1}^{m} \sin \alpha_{k}\right)^{2}+\left(m+\sum_{k=1}^{m} \cos \alpha_{k}^{2}\right\}\right]^{1 / 2}
\end{aligned}
$$

このように，本諭文の同時制御方式では直流假平均

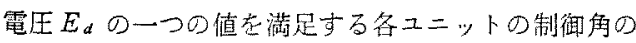
租合せは無数に存在することとなり，また交流側電流 に含まれる全高調波量も各ユニットの制維角の関数亡
なっているこよがわかる。従って，とこでは直流側平 均電圧を制的条件として交流側電流に含まれる全高調 波量を最小टする位相制御すなわち，制御角の組合せ を考えてみよう。いま，シグランジュの乘数を $\lambda$ とし て（6)式を畫直すと次のようになる。

$$
\begin{aligned}
F\left(\alpha_{i} \alpha_{2} \cdots \cdots \alpha_{m} \lambda\right) \\
=\frac{1}{\pi}\left\{m^{2} \pi-\sum_{k=1}^{m}(2 k-1) \alpha_{k}\right\} \\
-\frac{2}{\pi^{2}}\left\{S^{2}+(m+c)^{2}\right\}-\lambda\left\{\frac{E_{d}}{E_{m}}-\frac{1}{\pi}(m+c)\right\}
\end{aligned}
$$

但し, $S=\sum_{k=1}^{m} \sin \alpha_{k}, c=\sum_{k=1}^{m} \cos \beta_{k}$

往って，(7)式について， $\partial F / \partial \alpha_{k}=0$ および $\partial F / \partial \lambda$ $=0$ の連立方程式在解くことにより全高調波量を最小 とする制衙角の組合せ加得られる。

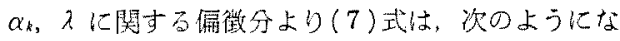
30

$$
\left.\begin{array}{rl}
\frac{\partial F}{\partial \alpha_{k}}= & -\frac{1}{\pi}(2 k-1)-\frac{2}{\pi^{2}}\left\{2 S \cos \alpha_{k}\right. \\
& \left.-2(m+c) \sin \alpha_{k}\right\}-\frac{\lambda}{\pi} \sin \alpha_{k}=0 \\
\frac{\partial F}{\partial \lambda}= & -\frac{E_{d}}{E_{m}}+\frac{1}{\pi}(m+c)=0
\end{array}\right\}
$$

ここて，(8)式の第1式若 $k$ につて和をとると，

$$
S=m^{2} \pi /(4 m-\lambda \pi)
$$

この(9)式を(8)式に代入すると

$$
\left.\begin{array}{rl}
\left(\frac{4 \pi E_{d}-\lambda \pi E_{m}}{E_{m}}\right) \sin \alpha_{k} \\
-\frac{4 m^{2} \pi}{4 m-\lambda \pi} \cos \alpha_{k}=\pi(2 k-1) \\
E_{d}=\frac{E_{m}}{\pi}\left(\sum_{k=1}^{m} \cos \alpha_{k}+m\right)
\end{array}\right)
$$

が得ら机る。従って各制御全 $\alpha_{k}$ は次の上うに求めら 机当。

$$
\begin{aligned}
\alpha_{k}= & \cos ^{-1}\left(\frac{\pi(2 k-1)}{\sqrt{\left(\frac{4 m^{2} \pi}{4 m-\pi \lambda}\right)^{2}+\left(\frac{4 \pi E_{d}-\pi \lambda E_{m}}{E_{m}}\right)^{2}}}\right) \\
& +\tan ^{-1}\left(\frac{\left.\frac{4 \pi E_{d}-\pi \lambda E_{m}}{\frac{-4 m^{2} \pi E_{m}}{4 m-\pi \lambda}}\right) \ldots \ldots \ldots(11)}{}\right)
\end{aligned}
$$

な扢この場合, 力率 $P F$ は次のように与元られる。

$$
P F=\sqrt{\frac{2}{\pi}} \frac{\sum_{k=1}^{m} \cos \alpha_{k}+m}{\sqrt{m^{2} \pi-\sum_{k=1}^{m}(2 k-1) \alpha_{k}}} .
$$


〈2.2〉等価妨害電流を最小とする制御 電力系 統の負荷電流に高調波が多量化含まれると，誘導現象 により近接平行する通信回線に誘導障害を与えるとと 怙周知のここであるが，電鉄回路の場合でむ同様で特 飞き電回路が大地㷌路回路在構成するので影響範囲は 大きい。起誘導回路に流れる高調波電流に上る妨害の 程度老表わ寸民度として等価妨害電流なる量力用いら れるが，こ礼は電話回線において $800 \mathrm{~Hz}$ を基準とし た各周波数の通話明り上う度の低下を重列関数として 評価した尚ので，これをJっとすると次のように与え られる。

$$
J_{p}=\sqrt{\sum_{n=1,3, \cdots}\left(K_{n} I_{n}\right)^{2}}
$$

但し, $I_{n}$ 二第 $n$ 調波電流, $K_{n}=$ 第 $n$ 調波の雉 意部严洒经数

徉って，本論文の同制御方式老適用して等洒妨害電 流を最小上する制笟では，乙れを目的関数しして各制 御ユニットの制御角を洪めるとととなる。第2図に市 け百交流側電流波形の第 $n$ 調波電流 $I_{n}$ は次の上うに 与范られ。

$$
I_{n}=\sqrt{\left(A_{n}^{2}+B_{n}^{2}\right) / 2}
$$

但し,

$$
\begin{aligned}
& A_{n}=\frac{2 I_{d}}{\pi n}\left(\sum_{k=1}^{m} \cos n \alpha_{k}+m\right) \\
& B_{n}=\frac{2 I_{d}}{\pi n}\left(\sum_{k=1}^{m} \sin n \alpha_{k}\right)
\end{aligned}
$$

従って，(13)式は次のようになる。

$$
\begin{aligned}
J_{p}^{2}= & \sum_{n=1}\left(\frac{2 K_{n} I_{d}}{\pi n}\right)^{2}\left(\sum_{k=1}^{m} \cos n \alpha_{k}+m\right)^{3} \\
& \left.+\left(\sum_{k=1}^{m} \sin n \alpha_{k}\right)^{2}\right\} \quad \ldots \ldots \ldots \ldots \ldots \ldots
\end{aligned}
$$

従って，等価好害電流最小制御では(3)式で示され

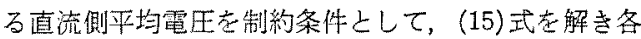
ユニットの制御角の組合せを決的るとととなる。いま ラダランジニの乘数をとして(15)式索喜えると，次 のようにな゙る。

$$
\begin{aligned}
F\left(\alpha_{1}, \alpha_{2}, \cdots \cdots, \alpha_{m} \lambda\right) \\
=\sum_{n=1}\left(\frac{2 I_{d} K_{n}}{\pi n}\right)^{2}\left\{\left(\sum_{k=1}^{m} \cos n \alpha_{k}+m\right)^{2}\right. \\
\left.\quad+\left(\sum_{k=1}^{m} \sin n \alpha_{k}\right)^{2}\right\}-\lambda\left\{\frac{E_{d}}{E_{m}}-\frac{1}{\pi}\right. \\
\left.\quad \times\left(\sum_{k=1}^{m} \cos \alpha_{l}+m\right)\right\} \ldots \ldots \ldots \ldots \ldots
\end{aligned}
$$

従って，(16) 式について $\partial F / \partial \alpha_{k}=0$ および $\partial F / \partial \lambda$ $=0$ の連立方程式を解くことにより各制御角力得られ る。 $\alpha_{k}, \lambda$ に関する病砤分上り

$$
\left.\begin{array}{rl}
\frac{\partial F}{\partial \alpha_{k}}= & \sum_{n=1}\left(\frac{2 I_{d} K_{m}}{\pi n}\right)^{2}\left(\frac{2 S_{n} \cos n \alpha_{k}}{n}\right) \\
& \left.-\frac{2\left(C_{n}+m\right) \sin n \alpha_{k}}{n}\right\} \\
& -\frac{\lambda}{\pi} \sin \alpha_{j}=0 \\
\frac{\partial F}{\partial \lambda}= & \frac{1}{\pi}(c+m)-\frac{E_{d}}{E_{m}}=0
\end{array}\right\}
$$

但し,

$$
\begin{aligned}
& S_{n}=\sum_{k=1}^{m} \sin n \alpha_{k}, \quad C_{n}=\sum_{k=1}^{m} \cos n \alpha_{k} \\
& c=\sum_{k=1}^{m} \alpha_{k}
\end{aligned}
$$

となる。(17)式估前記の場合と異なり，具体的に $\alpha_{k}$ の式を得ることはできないので数值解法は電子計算機 により、ニュートン・ラプソン法を用いて行なった。

〈2.3〉計算例 內上の各式を用いて整流器用主 変王器の二次側分割が 4 分割の場合について数值計算 を行ない四示すると，第 3 図〜第6图しなる。な挌 図の橫軸は，直流電圧の大きさを制約条件としている ので蒀流電匠とした。

第 3 圈は各ユニットの制御角と啹流電圧の関係を示 したすので，徉来の逐時制御方式では各ニニットを順 に $\pi$ 加ら雾の方向に制御し，第 1 ユニットの制卸終了

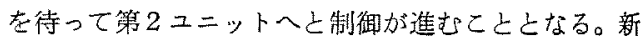
しい同時制御方式のうち，全高調波量最小においては 声流電王の満たす範用が $0 \leq E_{d} / E_{m} \leq 2 / \pi$ では第 1 工 ニットのみの这相制期となり，逐時制御亡同一で全高

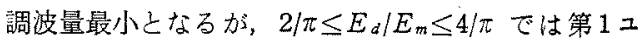
ニット，第 2 ユニット在同時に位相制御する場合に全 高調波量加最小となる。但し， $E_{d} / E_{m}=4 / \pi$ の直前で は第 1 ，第 2 ，第 3 ユニットを同時に制御する場合に 全高調波量が最小となっている。 $4 / \pi \leq E_{d} / E_{m} \leq 6 / \pi$ で 纯第 1 ，第 2 ，第 3 ユニットを同時に制獬する場合に 全高謂波量加最小となり， $E_{d} / E_{m}=6 / \pi$ の直前では， $E_{d} / E_{m}=4 / \pi$ の場合と同様な傾向しして，第 1 ，第 2 ,

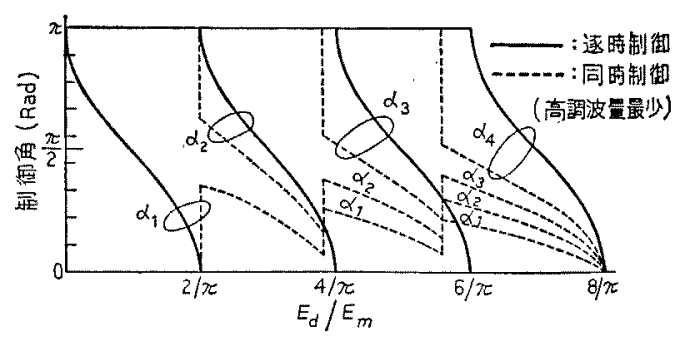

第 3 制御角の計算結果

Fig. 3. Calculation result of control angle. 


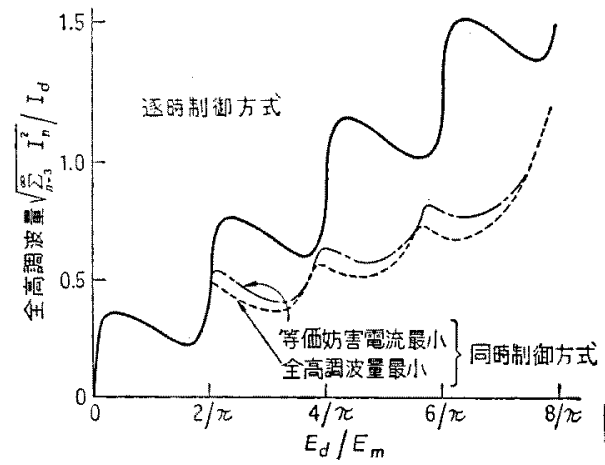

第 4 䍖全高調波量の計算結果

Fig. 4. Calculation result of whole harmonics in idealized current.

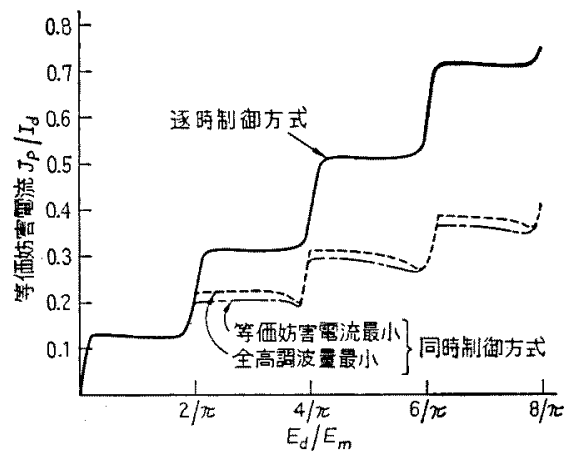

第 5 図等価妨㕩電流の計算結果

Fig. 5. Calculation result of equivalent interference current in idealized current.

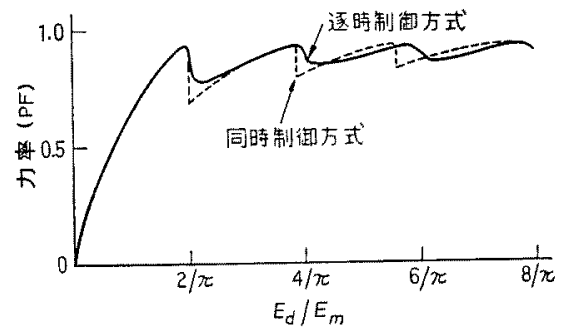

第 6 园力率の計算結果

Fig. 6. Calculation result of powerfactor.

第 3 ，第 4 ユニットを同時に制御する場合に全高調波 形量最小上なる結果を示した。次化等価妨害電流最小 の場合に拈りる制御争は，全高調波量最小の場合上若 干異なる值を示したが，大体似通った傾向しなってい る。

第4図は全高調波量の計算結果を示しだのである が，本同時制御方式に扔いては $E_{d} / E_{m} \geq 2 / \pi$ の場合， すなわち第 1 ，第 2 ユニットの同時制御の場合から効
果がみら扎， $E_{d} / E_{m}$ が大きくなるほじ全高調波量の 減少效果の大きいしとがわかる。また，等洒妨害電流 最小制御ては，全高調波量は若于增大する結果を示し た。

第 5 図は等価妨害電流の計算結果を示したおのであ る。逐時制御方式妨よび本同時制御方式いずれの埥合 も各ユニット制期開始時に最大となり，その後はほほ 一定值上なる傾向を示した。本同時制御方式では $2 / \pi$ 以上の直流電王の場合に減少効果加現われ，従来の逐 時制御に比ベて著しく等価妨害電流在減少することが できる。また，等価妨害電流最小制御では全高調波量 最小制唯の場合より更汇等価妨害電流の减少を訪るこ とができる。

第 6 図は力率 PF の計算結果を示したもので，従来 の逐時制御方式に比べて大きな相違はみら机ないが， 制御ユニットの替りめで，本同時制御方式が若千悪く なる場合と良くなる場合とがみられた。

\section{3. 実験方法並びに結果}

第 7 図に示すように, 整流器用主変圧器の二次側分 割数加 3 分割の㘯合を実験回路として構成し，逐時制 御方式と同時制御方式しの比較を行なった。なお図中 の記号は, $e$ : 交流電源 $(100 \mathrm{~V}), I_{p}:$, 交流電流計, $E_{p}$ : 交流電压計, $r$ : 電流検出用標準抵抗器 $(0.05 \Omega)$, $N M$ : 等価妨害電流計， $A_{n}$ : 周波数分析器， $T_{1}$ : 整 流器用主变圧器 (一次 $100 \mathrm{~V}$, 二次 $15 \mathrm{~V} \times 3$ ), $D$ : 混 合ブリッジ， $E_{d}$ : 直流電圧計， $I_{d}$ : 直流電流計， $X_{L}$ : 平滑リアクトル $(137 \mathrm{mH}), k$ : 負荷抵抗 $(11.8 \Omega) て ゙$ ある。

結果を示すと第 8 图〜第 10 四となる。第 8 园は各 部の電压，電流波形を示したもので，逐時制御方式で は上加ら $T_{1}$ の一次電生, 電流, 二次側巻線の電纴制 御中巻線の電流, ダイオード動作中巻線の電流, 直流 側電流，同笔压の䐓でる。また，同時制唂方式で は， $T_{1}$ の一次側電圧, 同電流, 二次側電生放よび各 巻楾電流, 直流側電流, 同電圧の順である。各波形で 判るように，第2四でしたモデル化電流波形との相

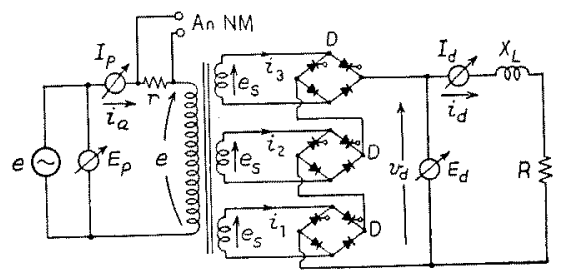

第 7 图実験回路

Fig. 7. Experimental circuit. 
逐時制御方式

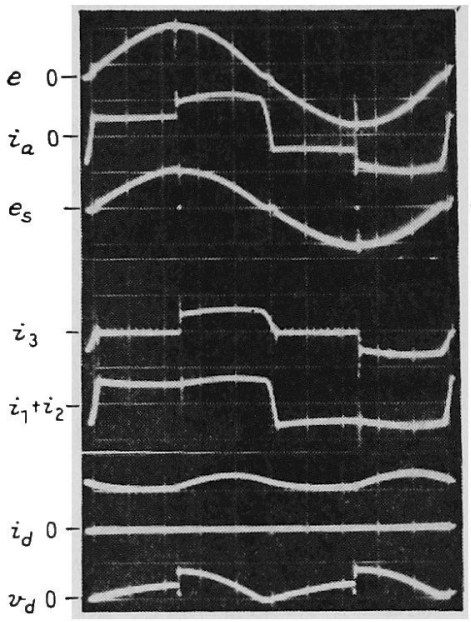

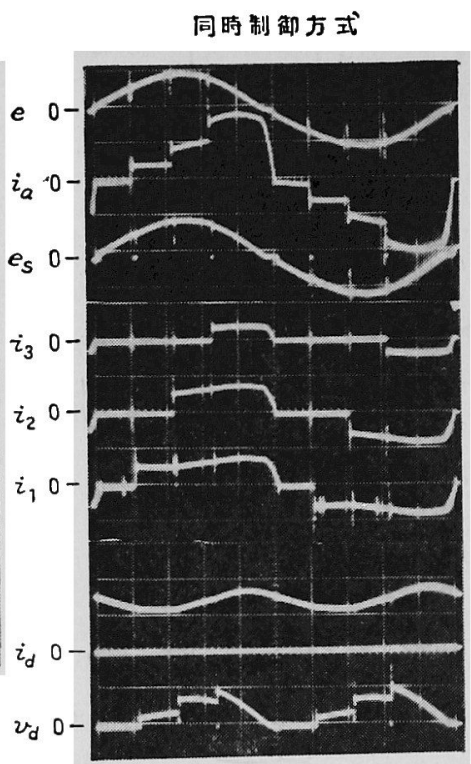

同時制䅉万式

第 8 図 実験中の各部電圧・電流波形

Fig. 8. Voltage and current waveform of experimental circuit.

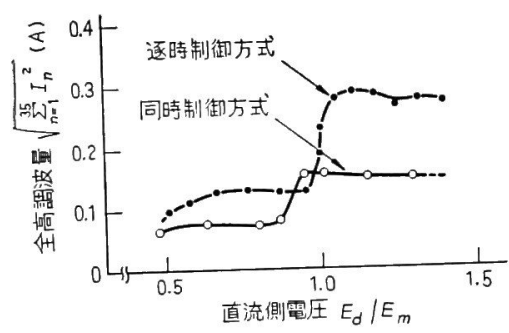

第 9 図全高調波量の実験結果

Fig. 9. Whole harmonics of line current in a experimental circuit.

違は，位相 $0, \pi に お け る$ 転流区間並びに直流電流の 脈動率沈いて若千異なっているが，制御位相におけ る転流区間ではほほ同様となり，巨視的には第 2 図の 電流波形のモデル化がほぼ満足されているものと考え られる。

第 9 図は直流側電圧と全高調波量（第 35 調波まて の合成) の実効值との関係を示したもので, 同時制御 万式は逐時制御方式に比へて直流側電圧の大きくなる ほど軽減効果の大きいととが加かり, 計算結果と同様 な傾向を示した。

第 10 図は直流側電圧上等価妨害電流との関係を示 したむので，結果は逐時制御方式に比べて $20 \%$ 程度 軽減する効果を示したが計算結果と比較して軽減効果 が少なかった。これは第8図の波形でもわかるように

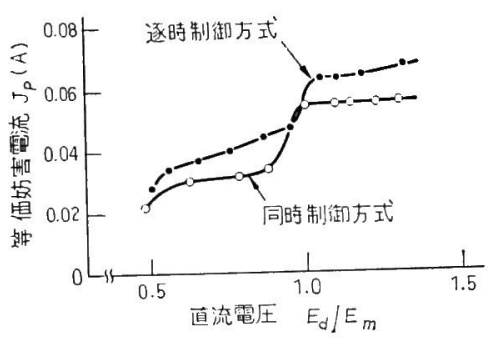

第 10 図等価妨害電流の実験結果

Fig. 10. Equivalent interference current of line current in a experimental circuit.

位相 $0, \pi$ における転流区間の影響によるためと考え られる。

\section{4. あとがき}

本論文は，サイリス夕制御整流回路において交流㑡 高調波電流の軽減を目的とするサイリスタ制御方式と して同時制御方式を提案し，その有効性を示した屯の である。この方式は交流側電流の全高調波量，等価妨 害電流または力率などを目的関数として各ユニットの 制御位相角を定め位相制御するもので，基本的にはて れによって最適制御が得られると考えられる。

なお，この同時制御方式に㧍ける実施上の具体的手 法についてはまだ検討を行なっていないが，例えばあ らかじめ制御位相角の組合せを計算しておく場合では ハード的に電気車のノッチに対応して各分割の制御パ 
ルスが発生するように制御装置を製作する必要があり そこでは大力電压に刘応して制御パルスの発生する制 御回路 ${ }^{(6)}$ が必要となる。この方法に上る問題点しして は負荷変動, 電車線とパンタの離線などによる電源電 王の変動に伴う処理などが考えられる。

また最近，整流回路の位相制御方るいは電気車の速

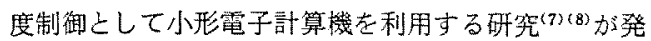
表されているが，とれらを利用する場合では最適制御 のための制御位相角計算と制御㭙間暑孔並びに外乱に 対する观置などの問題点を検討する必要が生じると考 えられる。

なっ，本同時制御方式による高調波軽減では交流つ ィルタによる場合のように電気車の重量，スペースに 与える影響当少なく，更に将来計画の小形電子計算機 に上る電気車の自動運転制御 ${ }^{(9)}$ 亿組込ま机るならば， 有効な高調波軽減手段上なり得る上考元られる。また 転流リアクタンスの增大など他の高調波軽減方法との
併用もできるので，より強力な高調波軽減詨策が可能 となる。

終りに，本研究は鉄道電化協会パリエレクトロニク ス委員会において，委員長の理科大学教授山田直平博 士をはじめ, 副委員長横浜国立大学教授池田吉堯博士 並びに委員各位の御討論亚びに御指導のあったととを 記して感謝の意を表したい。

(昭和 51 年 11 月 18 日受付，同 52 年 6 月 3 日丽受付)

\section{文献}

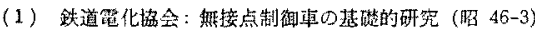
(2) 松楅・雨宮: 電学誌 90,1621 (昭 45-8)
(3) 松橋, 富沢: 昭46雪気四学会邀大 No. 783
(4) 蔽宮 *曾和 : 䈏学誌 93,54 (昭 48-2)

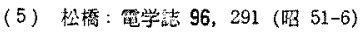
（6）卧井：路51電気四学会北陸支大 No. B-43
(7) 嵬入, 他: 昭51需匃、学全全大 No. 671
(8) 北屾・磨倉・保川：㫟50霆気四学会速大 No. 77
(9) 保川・金田・北山：昭52電気学会全大 No. 1057 